\title{
Isolation and kinetic properties of soldier termite (Amitermes silvestrianus Light, 1930) rhodanese
}

\author{
R.E. OKONJI ${ }^{1 *}$, H. A. ADEWOLE ${ }^{2}$, A. KUKU ${ }^{1}$ and F. K. AGBOOLA ${ }^{1}$ \\ ${ }^{1}$ Department of Biochemistry, Obafemi Awolowo University, Ile-Ife, Nigeria. \\ ${ }^{2}$ Department of Biochemistry, Faculty of Basic Medical Sciences, Ladoke Akintola University of Technology, \\ Ogbomoso, Oyo State, Nigeria. \\ *Corresponding author, E-mail: okonjire@yahoo.co.uk; reokonji@oauife.edu.ng,Tel: +2348060164991
}

\begin{abstract}
Rhodanese, a cyanide detoxifying enzyme, was isolated from soldier termite using ammonium sulphate fractionation, reactive blue affinity chromatography and gel filtration on Sephadex G-150. The enzyme had a specific activity of 7.9 RU per milligram of protein. The $\mathrm{K}_{\mathrm{m}}$ values of the substrates $\left(\mathrm{KCN}\right.$ and $\mathrm{Na}_{2} \mathrm{~S}_{2} \mathrm{O}_{3}$ ) were $7.0 \mathrm{mM}$ and $5.3 \mathrm{mM}$ respectively. The results of substrate specificity showed that the enzyme was specific for thiosulphate $\left(\mathrm{S}_{2} \mathrm{O}_{3}{ }^{2-}\right)$ when compared with other sulphur compounds. The native and subunit molecular weight of the enzyme was found to be 37,154 and 32,210 dalton respectively. The optimum $\mathrm{pH}$ and temperature of the enzyme activity were 8.0 and $55{ }^{\circ} \mathrm{C}$ respectively. $\mathrm{NH}_{4}{ }^{+}, \mathrm{Mn}^{2+}$, and $\mathrm{Ba}^{2+}$ had about $50 \%$ effect on the activity of the enzyme. However, $\mathrm{Hg}^{2+}, \mathrm{Zn}^{2+}$ and $\mathrm{Mg}^{2+}$ inhibited the enzyme considerably $(\leq 20 \%)$. The half-life of the enzyme at $40{ }^{\circ} \mathrm{C}, 50{ }^{\circ} \mathrm{C}, 60{ }^{\circ} \mathrm{C}, 70{ }^{\circ} \mathrm{C}$ and $80{ }^{\circ} \mathrm{C}$ were found to be $150.7,60.3,43.0$, 37.7 and 37.0 respectively.

(C) 2010 International Formulae Group. All rights reserved.
\end{abstract}

Keywords: Soldier termite; rhodanese; detoxification; sulphurtransferase enzyme; cyanide toxicity; insects.

\section{INTRODUCTION}

Rhodanese

(thiosulphate: cyanide sulphurtransferase EC. 2.8. I. I) is found in diverse tissues and organisms and probably acts as a general sulphurtransferase (Sorbo, 1953a,b; Westley, 1973; Sorbo, 1975; Westley, 1981; Nagahara et al.,1999; Aminlari et al., 2002). Rhodanese catalyses the transfer of the outer sulphate of thiosulphate to cyanide forming the products thiocyanate and sulphide (Lee et al., 1995). The reaction proceeds by way of double displacement mechanism in which a covalent enzyme-sulphur intermediate is formed
(Blumenthal and Heinrikson, 1971; Westley, 1981). The enzyme originally found in the mitochondrion has now been reported to also be located in the cytosol and other organelles (Nagahara et al., 1999; Agboola and Okonji, 2004). Its presence in the liver tissues of different animals have been demonstrated (Sorbo, 1953a; Jarabak and Westley, 1974; Blumenthal and Heinrikson, 1971; Lee et al., 1995; Nagahara et al., 1996; Agboola and Okonji, 2004; Akinsiku et al., 2009). However, its presence has also been shown in other tissues and organs (Sorbo, 1953a,b; Westley, 1981; Nagahara et al.,1999; 
Aminlari et al., 2002). Beesly et al. (1986) reported their findings on the distribution of rhodanese in both adults and larvae of insects. Furthermore, they found that the enzyme was not restricted to those species which encounter exogenous cyanide through feeding on cyanogenic plants (Beesly et al., 1986).

It is generally believed that the major function of rhodanese is cyanide detoxification (Smith and Urbanska, 1986; Buzaleh et al., 1990). However, some evidences had shown that the enzyme may be involved in other functions including formations of iron sulphur centres, and participation in energy metabolism (Bonomi et al., 1977; Ogata and Volini, 1990).

The soldier termite (a social insect) feeds generally on plant debris, decaying woods and grasses (apricot, almond, balsam fir, beech, cherry, citrus, etc) which have been shown to contain cyanogenic glycosides and on ingestion release cyanide (Woods and Calnan, 1976; Jagels, 1985; Gerozisis and Hadlington, 2001; Conn, 2008). Our attempt, therefore, to characterise rhodanese from soldier termite is for the purpose of biochemical comparison and to further understand the cyanide detoxification mechanism of the animal.

\section{MATERIALS AND METHODS Materials}

Ethylenediamine tetraacetic acid (EDTA) and low molecular weight calibration kit for electrophoresis were purchased from Sigma Chemical Company, St. Louis, Mo, USA. Sucrose, sodium chloride, phosphoric acid, manganese chloride tetrahydrate, ethanol, methanol, ammonium sulphate, glacial acetic acid, were purchased from BDH Chemical Limited, Poole England. Potassium chloride, sodium dodecyl sulphate (SDS), acrylamide and N, N'-methylene bisacrylamide (MBA), ammonium persulphate, N,N,N',N'-tetramethylenediamine (TEMED) and Sephadex G series, are from Pharmacia Fine Chemicals, Uppsala, Sweden. All other reagents were of analytical grade.

Soldier termites were collected from a farm land in Ikenne, Ogun State, Nigeria.

\section{Enzyme extraction and purification}

The soldier termites were soaked in saline solution after allowing the tissues to pass through a sieve to remove sand and other dirty particles. The tissue weighing $100 \mathrm{~g}$ was homogenised in a Warring Blender in nine volumes of the homogenisation buffer containing $0.25 \mathrm{M}$ sucrose in $0.1 \mathrm{M}$ acetate glycine buffer containing $10 \mathrm{mM}$ sodium thiosulphate. The homogenate obtained was subjected to centrifugation at $6,000 \mathrm{rpm}$ using Beckman Optima LE-80K Ultracentrifuge for $30 \mathrm{~min}$. The supernatant was filtered using a double-layered cheese cloth and the precipitate was rehomogenised in 2 volumes of homogenisation buffer and centrifuged under the same condition. The supernatants were then pooled together and brought to $70 \%$ ammonium sulphate concentration, and left for $12 \mathrm{hr}$. The resulting precipitate obtained after centrifugation at $6,000 \mathrm{rpm}$ for $30 \mathrm{~min}$. was dialyzed against several changes of 50 $\mathrm{mM}$ citrate buffer, $\mathrm{pH} 5.0$ containing $10 \mathrm{mM}$ $\mathrm{Na}_{2} \mathrm{~S}_{2} \mathrm{O}_{3}$. The dialysate was centrifuged at $6,000 \mathrm{rpm}$ for $30 \mathrm{~min}$ to remove insoluble material. This was used for the affinity chromatography step.

The Reactive Blue-2 agarose was equilibrated with $50 \mathrm{mM}$ citrate buffer $\mathrm{pH} 5.0$ according to the manufacturer's manual. The gel was packed into a $2.5 \times 20 \mathrm{~cm}$ glass column. The enzyme fraction from the previous step was layered on it. Fractions of $4 \mathrm{ml}$ were collected from the column at the rate of $36 \mathrm{ml}$ per hour. The protein was monitored at $280 \mathrm{~nm}$. The fractions were also assayed for rhodanese activity. The fractions with high enzyme activities were pooled and preserved in $50 \%$ glycerol-citrate buffer solution.

Sephadex G 150 gel resin was prepared by swelling $20 \mathrm{~g}$ in distilled water for 3 days.

The resin was then washed with several changes of $0.2 \mathrm{M}$ phosphate buffer containing $10 \mathrm{mM}$ sodium thiosulphate, $\mathrm{pH} 7.0$ and then packed into $2.5 \times 40 \mathrm{~cm}$ glass column and equilibrated with the same buffer. The dialyzed protein from the affinity chromatography step was layered on the column. Fractions of $4 \mathrm{ml}$ were collected from the column at a rate of $12 \mathrm{ml}$ per hour. 
Protein profile was monitored spectrophotometrically at $280 \mathrm{~nm}$ and assayed for rhodanese activity.

The active fractions were pooled and preserved in 50\% glycerol-phosphate buffer solution.

\section{Enzyme assay and protein concentration determination}

Principle of the assay was based on the colorimetric method for the determination of thiocyanate formation. Rhodanese activity was measured using sodium thiosulphate $\left(\mathrm{Na}_{2} \mathrm{~S}_{2} \mathrm{O}_{3}\right)$ as substrate, as previously described by Agboola and Okonji (2004).

Bradford method (1976) was used routinely to measure the protein concentration of the enzyme using bovine serum albumin (BSA) as a standard.

\section{Native molecular weight determination}

The native molecular weight was determined on a calibrated Sephadex G-150 column $(2.5 \times 40 \mathrm{~cm})$. The standard proteins were gamma-globulin: 150,000 dalton; creatinine phosphokinase (CPK): 81,000 dalton; BSA: 66,000 dalton; ovine albumin: 45,000 dalton; $\alpha$-chymotrypsinogen A: 25,000 dalton. In calibrating the column, $5 \mathrm{ml}$ of each standard of $5 \mathrm{mg} / \mathrm{ml}$ was applied to the column separately. The column was eluted at a flow rate of $10 \mathrm{ml} / \mathrm{h}$ with a $5 \mathrm{mM}$ tris- $\mathrm{HCl}$ buffer, $\mathrm{pH}$ 7.2. Fractions of $4 \mathrm{ml}$ were collected and monitored for protein at $280 \mathrm{~nm}$. The void volume $\left(\mathrm{V}_{\mathrm{o}}\right)$ of the column was determined by the elution volume of Blue Dextran.

\section{Determination of subunit molecular weight} Sodium dodecyl sulphate polyacrilamide gel electrophoresis (SDSPAGE) was performed, for ascertaining the purity of the preparation in accordance with the procedure of Weber and Osborn (1975) on $10 \%$ rod gels using the phosphate buffer system. The sample preparation, application and running conditions were performed according to Weber and Osborn (1975) instruction. The standard proteins were as contained in Sigma molecular weight markers Calibration kit for SDS-polyacrilamide gel electrophoresis (Daltons Mark VII -L, low molecular weight marker range 14,00067,000).

\section{Kinetic studies}

The $\mathrm{K}_{\mathrm{m}}$ and $\mathrm{V}_{\max }$, were determined by varying the concentration of $\mathrm{KCN}$ (between $10 \mathrm{mM}$ and $60 \mathrm{mM}$ ) at fixed concentrations of $\mathrm{Na}_{2} \mathrm{~S}_{2} \mathrm{O}_{3} \quad(50 \mathrm{mM})$ and also varying the concentration of $\mathrm{Na}_{2} \mathrm{~S}_{2} \mathrm{O}_{3}$ (between $50 \mathrm{mM}$ and $600 \mathrm{mM}$ ) at fixed concentrations of $\mathrm{KCN}$ $(50 \mathrm{mM})$. The kinetic parameters were then estimated from the double reciprocal plots.

\section{Specificity studies}

Different sulphur compounds (thiosulphate, sulphate, sulphite and sulphide) were used as substrates at $100 \mathrm{mM}$ and 200 $\mathrm{mM}$ final concentration in a typical rhodanese assay mixture.

\section{Effect of pH}

The enzyme preparation above was assayed at $\mathrm{pH}$ between 5 and 11 using $50 \mathrm{mM}$ citrate buffer ( $\mathrm{pH}$ 5.0-6.5), $10 \mathrm{mM}$ phosphate buffer ( $\mathrm{pH} 7.0-8.0)$ and $10 \mathrm{mM}$ borate buffer (pH 8.5-11.0). The assay mixture of $1.0 \mathrm{ml}$ contained $0.1 \mathrm{M}$ of the required buffer, 0.05 $\mathrm{M} \mathrm{KCN}, 0.05 \mathrm{M} \mathrm{Na}_{2} \mathrm{~S}_{2} \mathrm{O}_{3}$ and $20 \mu \mathrm{l}$ of the enzyme solution.

\section{Effect of temperature}

The enzyme $(20 \mu \mathrm{l} ; 1.02 \mathrm{mg} / \mathrm{ml})$ was assayed at temperatures between $0{ }^{\circ} \mathrm{C}$ and 80 ${ }^{\circ} \mathrm{C}$ to investigate the effect of temperature on the activity of the enzyme. The assay mixture was first incubated at the indicated temperature for $10 \mathrm{~min}$ before the addition of a $20 \mu \mathrm{l}$ aliquot of the enzyme. The heat stability of the enzyme was also investigated between $30{ }^{\circ} \mathrm{C}$ and $80{ }^{\circ} \mathrm{C}$. Aliquots of $1.0 \mathrm{ml}$ of the purified enzyme was incubated at the indicated temperature.

\section{Effect of cations}

The effect of the following salts ammonium chloride, manganese chloride, mercuric chloride, barium chloride, magnesium chloride and zinc chloride on the activity of rhodanese was investigated by assaying the enzyme at $0.1 \mathrm{mM} 0.5 \mathrm{mM}$ and $1.0 \mathrm{mM}$ final salt concentrations in the reaction mixture. 


\section{RESULTS}

Purification of rhodanese

The results of the purification of rhodanese from soldier termite are summarized in Table 1. The elution profiles after reactive blue affinity chromatography and gel filtration on Sephadex G-150 are shown in Figures 1 and 2 respectively.

\section{Molecular weight determination}

The native molecular weight was found to be 37,154 dalton on Sephadex G-150 (Figure 3) while the subunit molecular weight obtained from SDS-PAGE was approximately 32,210 dalton (Figure 4).

\section{Kinetic parameters and specificity studies}

Figures 5 and 6 shows the LineweaverBurk plots for fixed concentration of thiosulphate and $\mathrm{KCN}$ respectively. The $\mathrm{K}_{\mathrm{m}}$ values for $\mathrm{KCN}$ and $\mathrm{Na}_{2} \mathrm{~S}_{2} \mathrm{O}_{3}$ were $7.0 \mathrm{mM}$ and $5.3 \mathrm{mM}$ respectively while the $\mathrm{V}_{\max }$ values for the two substrates $(\mathrm{KCN}$ and $\mathrm{Na}_{2} \mathrm{~S}_{2} \mathrm{O}_{3}$ ) were 1.7 and 5.0 RU respectively (Table 2). Table 3 shows the $K_{m}$ and $V_{\text {max }}$ values of rhodanese from other sources. Figure 7 shows the Lineweaver-Burk plot of sulphide as substrate. The $\mathrm{K}_{\mathrm{m}}$ value obtained from the plot was $9.0 \mathrm{mM}$ and a $\mathrm{V}_{\max }$ of 41.7 RU. The results of the specificity studies are presented in Table 4.

\section{Effects of pH on enzyme activity}

There was an increase in the enzyme activity between $\mathrm{pH} 7.0$ and 8.5. An optimum $\mathrm{pH}$ of 8.0 was observed (Figure 8 ).

\section{Effects of temperature on enzyme activity}

The maximum activity of the enzyme was obtained at a temperature of $55{ }^{\circ} \mathrm{C}$ (Figure 9). The heat stability experiment showed that the enzyme was stable at temperature up to $60{ }^{\circ} \mathrm{C}$ for 40 minute and a decrease in the activity at $70{ }^{\circ} \mathrm{C}$ and $80{ }^{\circ} \mathrm{C}$ (Figure 10). Figure 11 shows the plot of $\log$ of $\%$ residual activity against time for the determination of half-life of the enzyme. The enzyme was found to have half-life of 150.7 , 60.3, 43.0, 38.0 and 16 min at $40{ }^{\circ} \mathrm{C}, 50{ }^{\circ} \mathrm{C}, 60$ ${ }^{\circ} \mathrm{C}, 70{ }^{\circ} \mathrm{C}$ and $80{ }^{\circ} \mathrm{C}$ respectively (Table 5).

\section{Effects of cations on enzyme activity}

The results of the effect of various cations on the activity of the enzyme is presented in Figure 12. The results showed that $\mathrm{NH}_{4}^{+}, \mathrm{Mn}^{2+}$, and $\mathrm{Ba}^{2+}$ had about $50 \%$ effect on the activity of the enzyme. However, the concentrations $(0.1 \mathrm{mM}, 0.5 \mathrm{mM}$ and 1.0 $\mathrm{mM})$ of $\mathrm{Hg}^{2+}, \mathrm{Zn}^{2+}$ and $\mathrm{Mg}^{2+}$ inhibited the enzyme considerably as seen in Figure 12

Table 1: The purification profile of soldier termite rhodanese.

\begin{tabular}{|l|l|l|l|l|l|}
\hline & $\begin{array}{l}\text { Total } \\
\text { Protein (mg) }\end{array}$ & $\begin{array}{l}\text { Total } \\
\text { Activity } \\
\text { (RU) }\end{array}$ & $\begin{array}{l}\text { Specific } \\
\text { Activity } \\
\text { (RU/mg) }\end{array}$ & $\begin{array}{l}\text { Purification } \\
\text { Fold }\end{array}$ & Yield (\%) \\
\hline Crude Extract & $4,161.58$ & $5,507.7$ & 1.3 & 1.0 & 100 \\
\hline $\begin{array}{l}70 \% \\
\text { Ammonium } \\
\text { Sulphate }\end{array}$ & $2,425.9$ & $4,610.2$ & 2.5 & 1.9 & 58.3 \\
\hline $\begin{array}{l}\text { Reactive Blue- } \\
\text { Affinity } \\
\text { Chromatography }\end{array}$ & 765.7 & $4,018.2$ & 5.2 & 4.0 & 18.4 \\
\hline $\begin{array}{l}\text { Sephadex G-150 } \\
\text { gel filtration } \\
\text { Chromatography }\end{array}$ & 432.8 & $3,421.1$ & 7.9 & 6.1 & 10.42 \\
\hline
\end{tabular}

Each step was carried out as described in the test. Activity was measured by estimating the amount of thiocyanate formed. Protein concentration was determined by the method of Bradford (1976). One rhodanese unit is taken as the amount of enzyme which under the given conditions will produce an optical density reading of 1.08 at $460 \mathrm{~nm}$. 


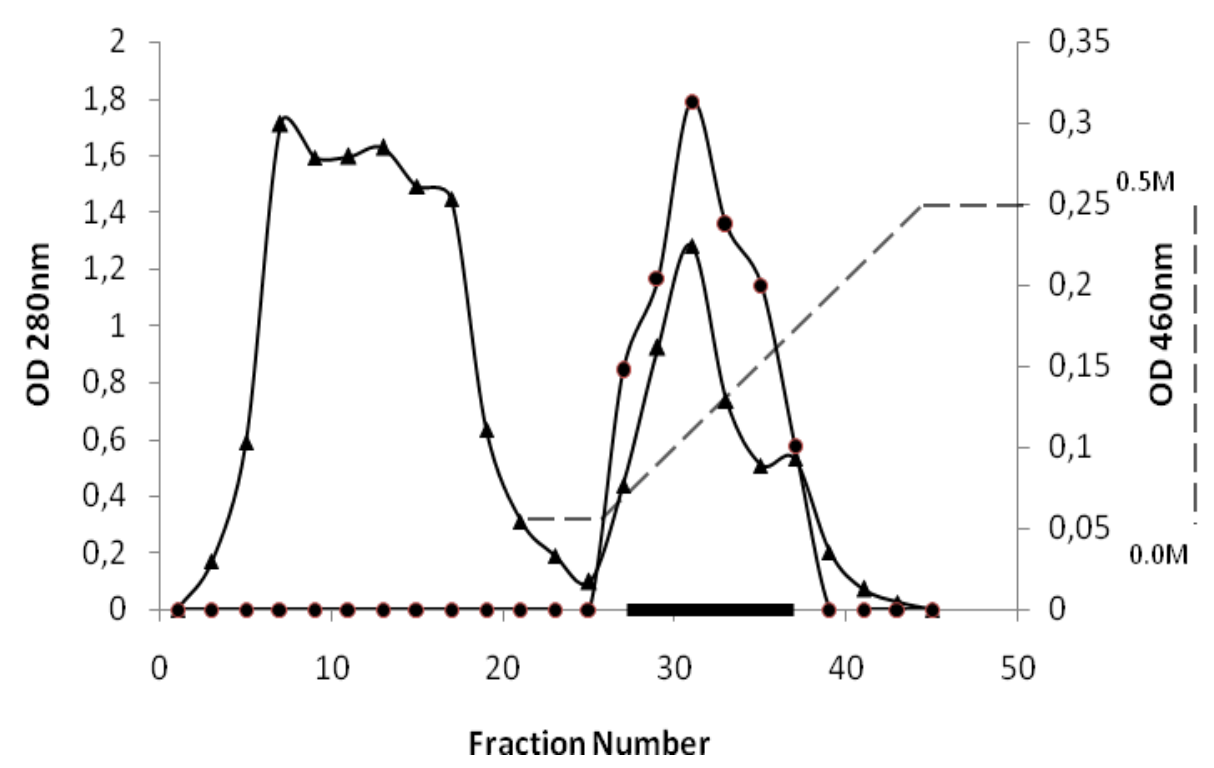

Figure 1: The elution profile of soldier termite after Reactive Blue-2 Agarose affinity chromatography. The $70 \%$ ammonium sulphate dialysate was layered on the column $(2.5 \times 20 \mathrm{~cm})$ which was first washed with $200 \mathrm{ml}$ of citrate buffer, $\mathrm{pH} 5.0$ containing $10 \mathrm{mM}$ sodium thiosulphate and later eluted with $200 \mathrm{ml}$ linear gradient of $0.0-0.5 \mathrm{M} \mathrm{NaCl}$ at a flow rate of $36 \mathrm{ml} / \mathrm{hr}$. Fractions of $4 \mathrm{ml}$ were collected.

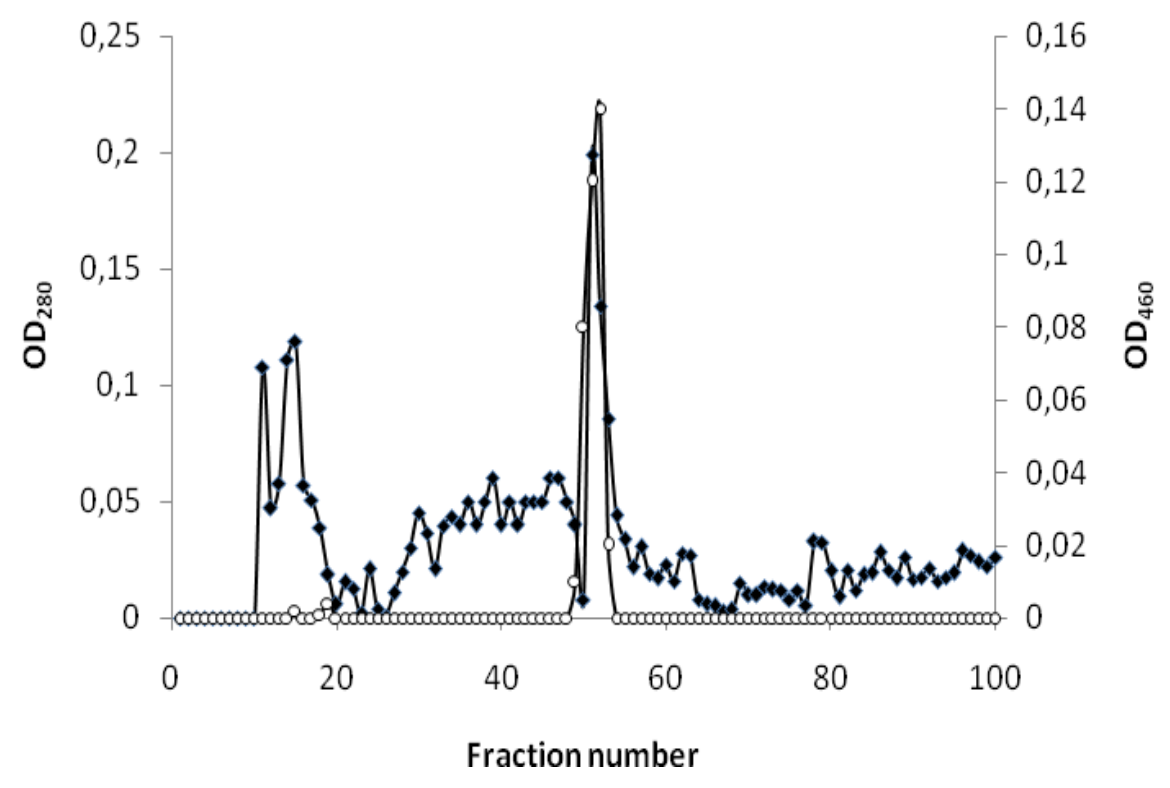

Figure 2: The elution profile of soldier termite after Sephadex G-150 chromatography. The fraction from the Reactive Blue-2 Agarose affinity chromatography was layered on the column $(2.5 \times 40 \mathrm{~cm})$ which was washed with $500 \mathrm{ml}$ of $0.2 \mathrm{M}$ phosphate buffer, $\mathrm{pH} 7.0$ containing $10 \mathrm{mM}$ sodium thiosulphate at a flow rate of $12 \mathrm{ml} / \mathrm{hr}$. Fractions of 4 $\mathrm{ml}$ were collected. 


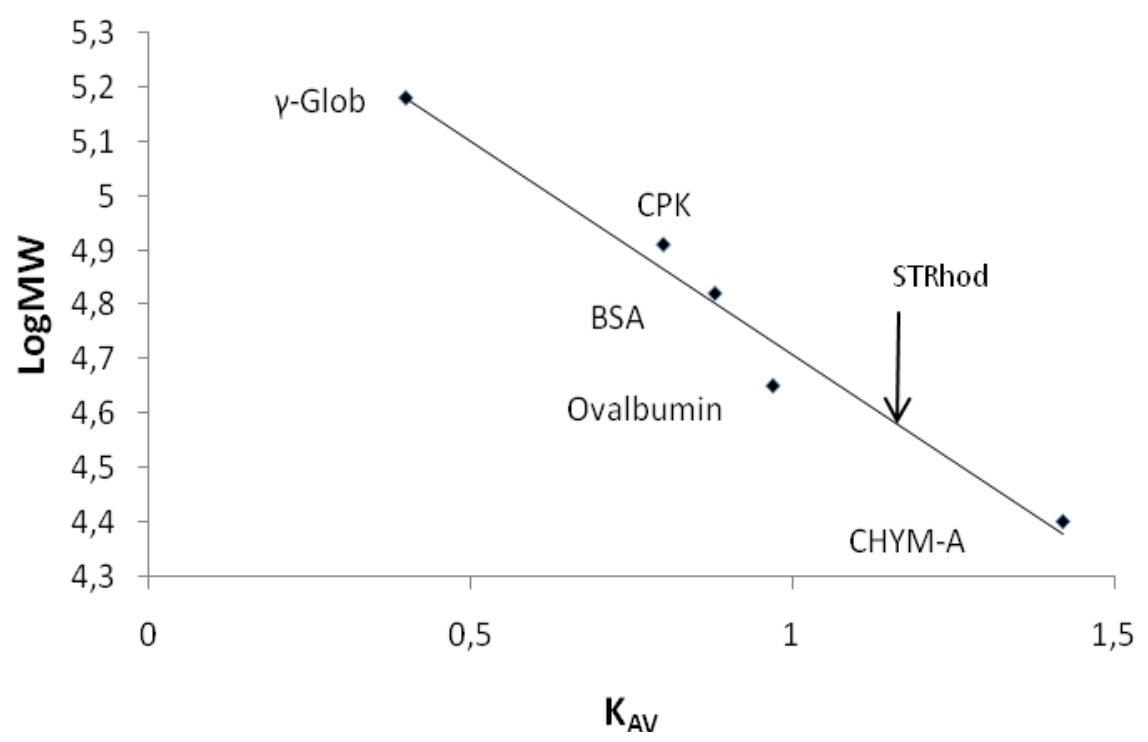

Figure 3: Calibration curve on Sephadex-G 150 for native molecular weight determination of soldier termite rhodanese. The native molecular weight was determined on a Sephadex-G 150 column $(2.5 \times 40 \mathrm{~cm})$. The standard proteins as indicated on the curve are chymotrypsinogen A (CHYM-A), ovalbumin, bovine serum albumin (BSA), creatinine phosphokinase (CPK), $\gamma$-globulin $(\gamma$-Glob). Soldier termite rhodanese (STRhod) is indicated with the arrow.

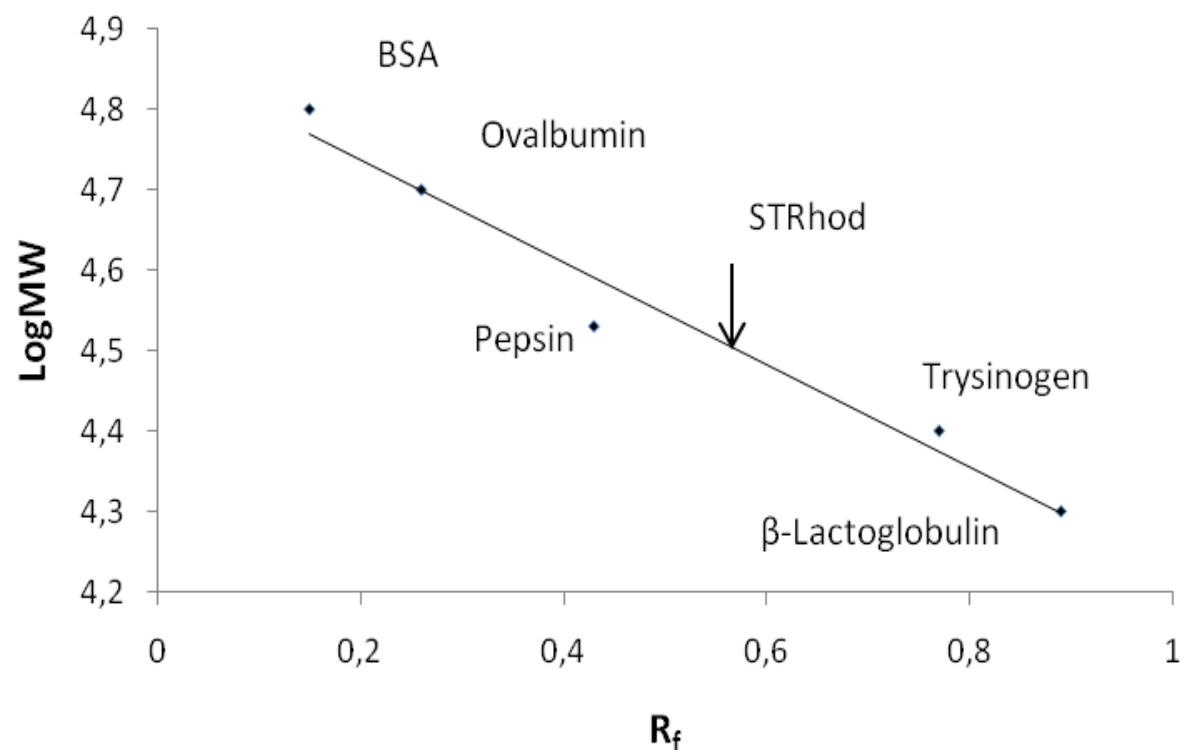

Figure 4: Calibration curve on 10\% SDS-PAGE for subunit molecular weight determination of soldier termite rhodanese. The subunit molecular weight was determined on 10\% SDS-PAGE using $0.2 \mathrm{M}$ phosphate buffer system. The standard proteins as indicated on the curve are ovalbumin, bovine serum albumin (BSA), $\beta$-lactoglobulin, pepsin and trypsinogen. Soldier termite rhodanese (STRhod) is indicated with the arrow. 


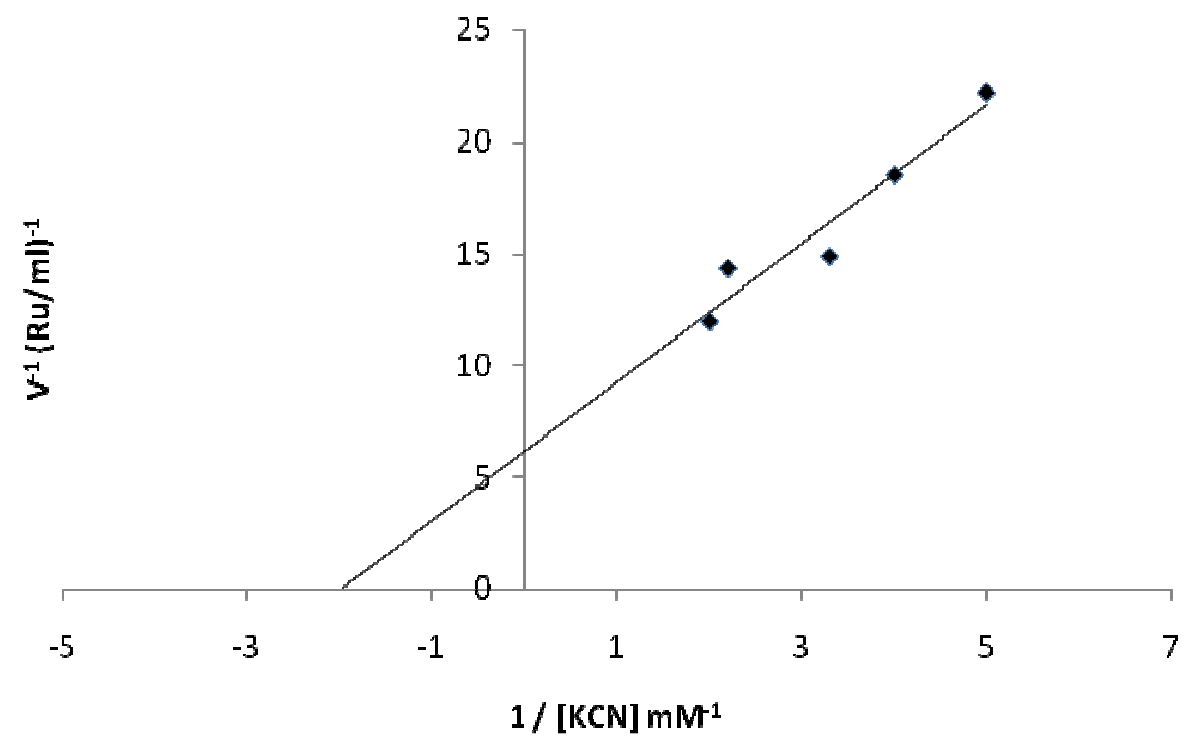

Figure 5: Effect of varying the concentration of potassium cyanide. Lineweaver-Bulk plots showing the effect of varying concentration of potassium cyanide at fixed concentration of sodium thiosulphate $\left(\mathrm{Na}_{2} \mathrm{~S}_{2} \mathrm{O}_{3}\right)$. The reaction mixture contained $25 \mathrm{mM}$ borate buffer, $\mathrm{pH} 9.4$, potassium cyanide concentration between $50 \mathrm{mM}$ and $200 \mathrm{mM}$, the indicated concentration of sodium thiosulphate and $20 \mu 1$ of enzyme solution in a final volume of $1.0 \mathrm{ml}$.

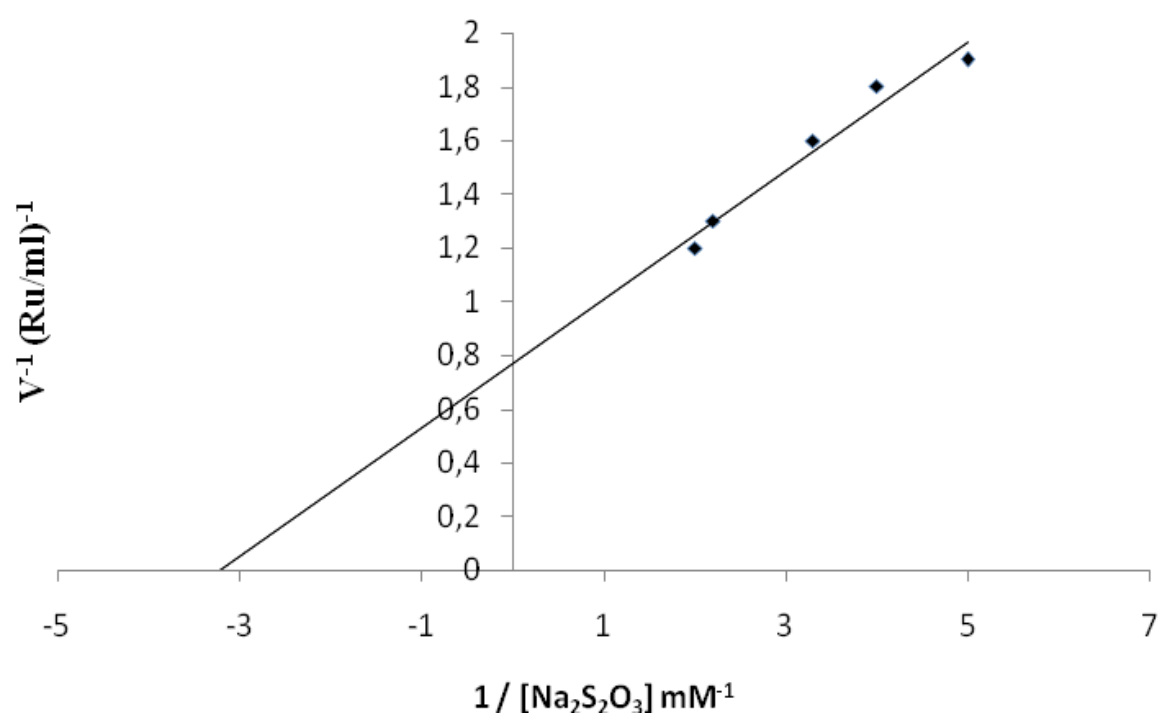

Figure 6: Effect of varying concentration of sodium thiosulphate. Lineweaver-Bulk plots showing the effect of varying concentration of sodium thiosulphate at fixed concentration of potassium cyanide $(\mathrm{KCN})$. The reaction mixture contained $25 \mathrm{mM}$ borate buffer, $\mathrm{pH} 9.4$, sodium thiosulphate concentration between $100 \mathrm{mM}$ and $500 \mathrm{mM}$, the indicated concentration of potassium cyanide and $20 \mu \mathrm{l}$ of enzyme solution in a final volume of $1.0 \mathrm{ml}$. 


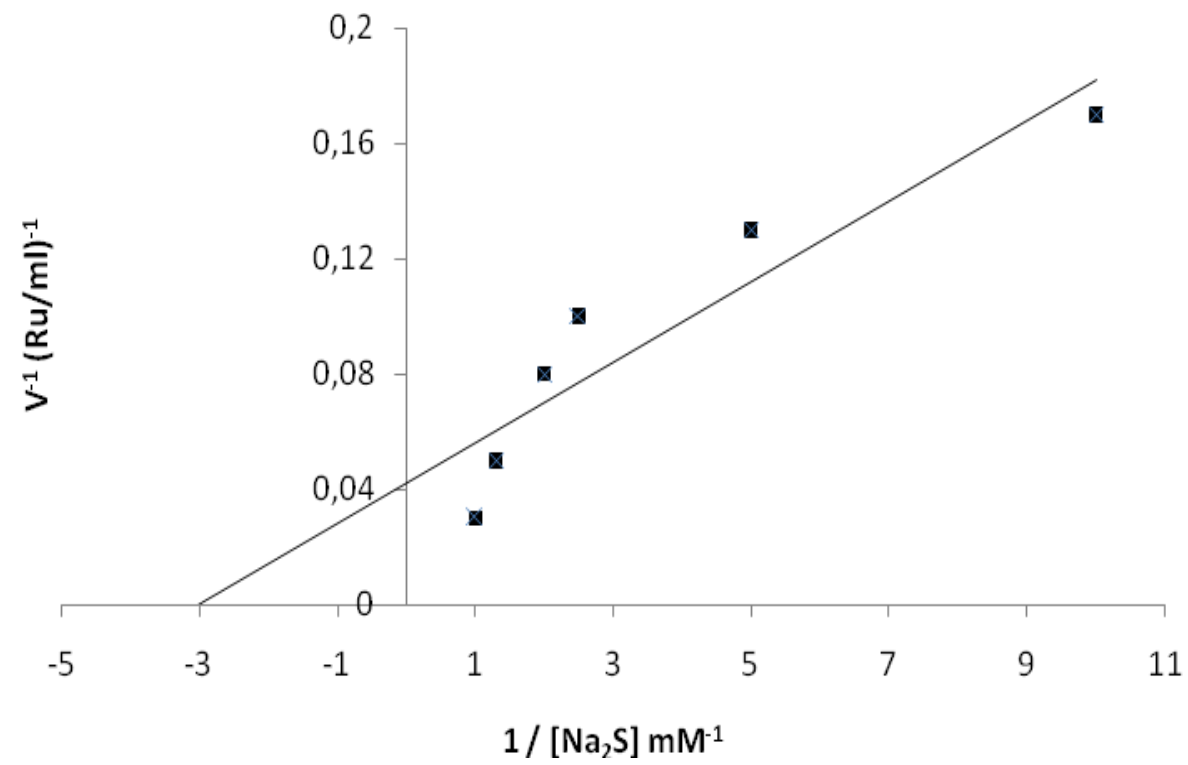

Figure 7: Effects of varying concentration of sodium sulphide. Lineweaver-Bulk plots showing the effect of varying concentration of sodium sulphide at fixed concentration of potassium cyanide $(\mathrm{KCN})$. The reaction mixture contained $25 \mathrm{mM}$ borate buffer, $\mathrm{pH} 9.4$, sodium sulphide concentration between $100 \mathrm{mM}$ and $600 \mathrm{mM}$, the indicated concentration of potassium cyanide and $20 \mu 1$ of enzyme solution in a final volume of $1.0 \mathrm{ml}$.

Table 2: Kinetic parameters of soldier termite rhodanese.

\begin{tabular}{lccc}
\hline Substrates & $\mathbf{K C N}$ & $\mathbf{N a} \mathbf{S}_{\mathbf{2}} \mathbf{O}_{\mathbf{3}}$ & $\mathbf{N a} \mathbf{S}$ \\
\hline $\mathrm{K}_{\mathrm{m}}(\mathrm{mM})$ & $7.0 \pm 0.12$ & $5.3 \pm 2.41$ & $9.0 \pm 0.11$ \\
$\mathrm{~V}_{\max }(\mathrm{RU} / \mathrm{ml})$ & $2.0 \pm 0.61$ & $17.2 \pm 1.54$ & $41.7 \pm 4.12$ \\
\hline
\end{tabular}

The $K_{m}$ and $V_{\max }$ values are means of three determinations. The kinetic parameters $\left(K_{m}\right.$ and $\left.V_{\max }\right)$ for the substrates were determined according to the method of Agboola and Okonji (2004).

Table 3: Kinetic parameters of rhodanese from different species.

\begin{tabular}{lcc}
\hline & \multicolumn{2}{c}{$\mathbf{K}_{\mathbf{m}}(\mathbf{m M})$} \\
\hline Organisms & $\mathbf{K C N}$ & $\mathbf{N a}_{\mathbf{2}} \mathbf{S}_{\mathbf{2}} \mathbf{O}_{\mathbf{3}}$ \\
\hline Soldier termite $^{\mathrm{a}}$ & 7.0 & 5.3 \\
Bovine liver $^{\mathrm{b}}$ & 19.0 & 6.5 \\
Human liver $^{\mathrm{c}}$ & 9.5 & 4.5 \\
Mouse liver $^{\mathrm{d}}$ & 12.5 & 8.3 \\
Bat liver $^{\mathrm{e}}$ & 13.36 & 19.15 \\
Cat liver $^{\mathrm{f}}$ & 25.4 & 18.6 \\
${ }^{\mathrm{a}}=$ present work; $^{\mathrm{b}}=$ Sorbo (1953a); ${ }^{\mathrm{c}}=$ Jarabak and Westley (1974); & d= Lee et al. (1995); \\
${ }^{\mathrm{e}}=$ Agboola and Okonji (2004); ${ }^{\mathrm{f}}=$ Akinsiku et al. (2009).
\end{tabular}


Table 4: Percentage residual activity of alternate substrates.

\begin{tabular}{lcccc}
\hline Conc $(\mathbf{m M})$ & $\mathbf{S O}_{4}{ }^{2-}$ & $\mathbf{S O}_{3}{ }^{2-}$ & $\mathbf{S}^{2-}$ & $\mathbf{S}_{\mathbf{2}} \mathbf{O}_{\mathbf{3}}{ }^{2-}$ \\
\hline $100(\mathrm{mM})$ & 5.20 & 0.00 & 32.30 & 100 \\
$200(\mathrm{mM})$ & 5.20 & 8.70 & 42.10 & 100 \\
\hline
\end{tabular}

The enzyme assay was carried out using standard assay mixture containing each salt at final concentrations of $100 \mathrm{mM}$ and $200 \mathrm{mM}$. The values are means of triplicate determinations. Conc $=$ Concentration.

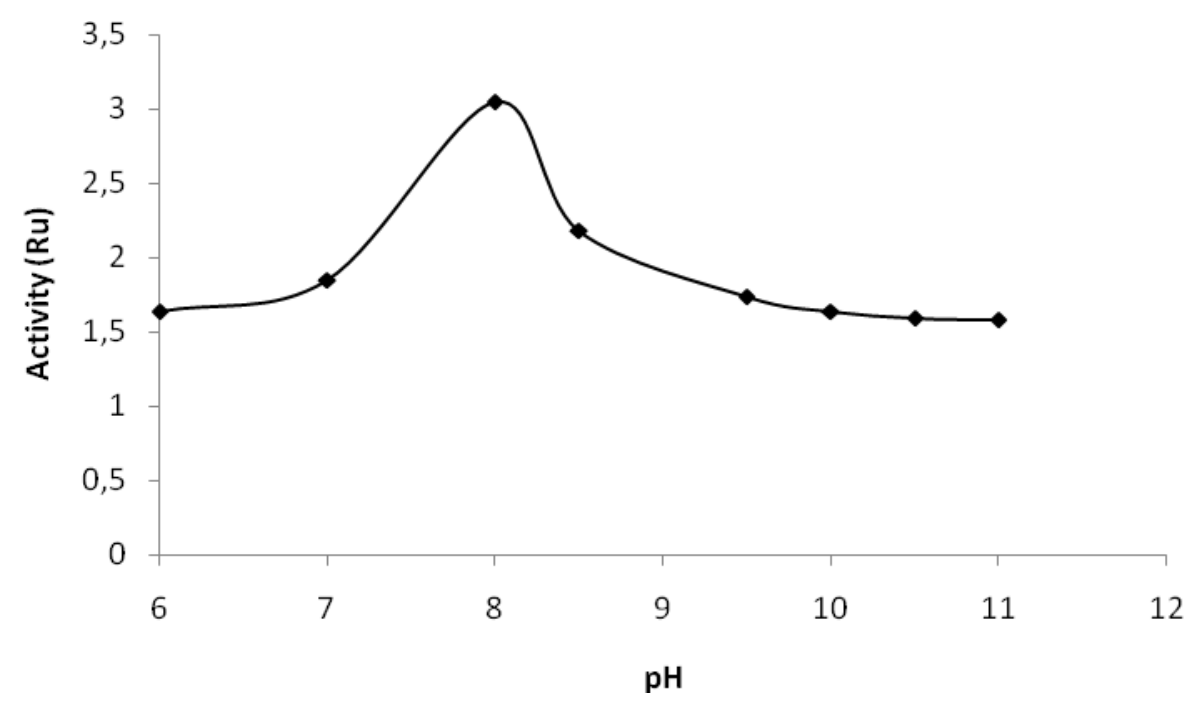

Figure 8: Effect of $\mathrm{pH}$ on the activity of soldier termite rhodanese. The assay mixture contained $50 \mathrm{mM}$ of the appropriate buffer, $50 \mathrm{mM} \mathrm{KCN}, 50 \mathrm{mM} \mathrm{Na} \mathrm{S}_{2} \mathrm{O}_{3}$ and $20 \mu \mathrm{l}$ of enzyme solution in a final volume of $1.0 \mathrm{ml}$. Determination of $\mathrm{pH}$ optimum using $10 \mathrm{mM}$ citrate , $\mathrm{pH}$ 4.0-6.5; $10 \mathrm{mM}$ phosphate buffer, $\mathrm{pH}$ 7.0-8.0; $10 \mathrm{mM}$ Tris-HCl buffer, $\mathrm{pH}$ 6-9 and $10 \mathrm{mM}$ borate buffer, 9.5-10.5.

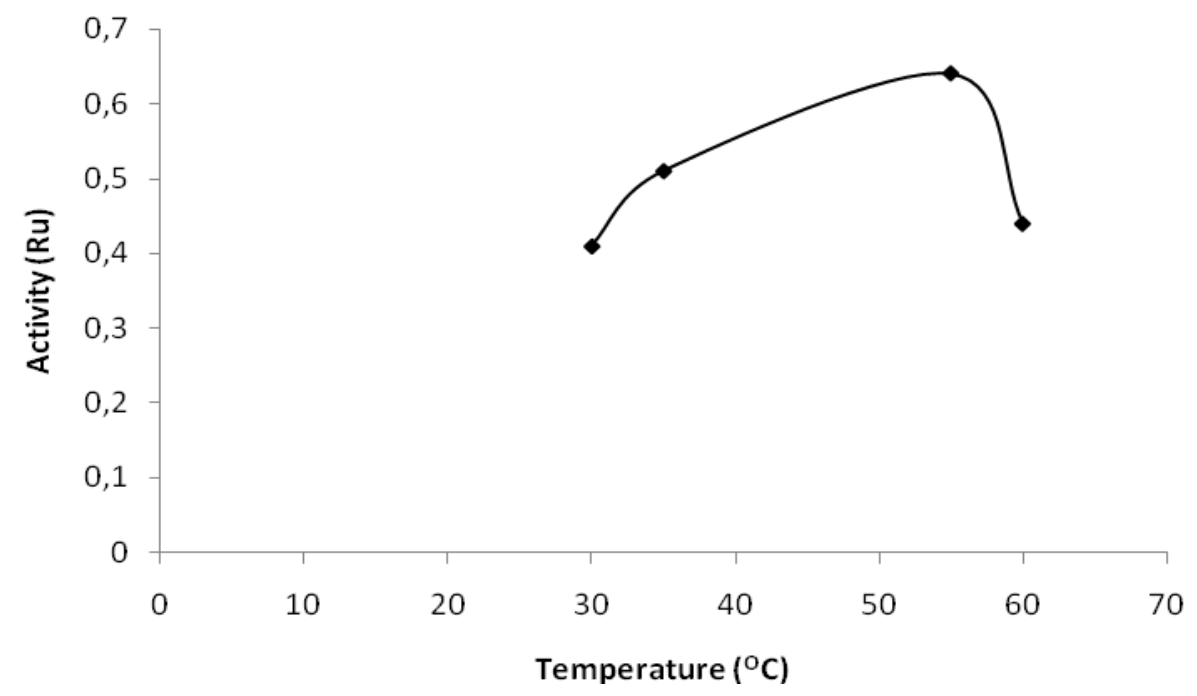

Figure 9: The activity-temperature profile indicating the optimum temperature. Assays were in a $25 \mathrm{mM}$ borate buffer, $\mathrm{pH} 9.4$ at temperatures between $30^{\circ} \mathrm{C}$ and $70{ }^{\circ} \mathrm{C}$. The assay mixture was first incubated with the enzyme at the indicated temperatures for $1 \mathrm{~min}$ before the reaction was terminated. 
R E OKONJI et al. / Int. J. Biol. Chem. Sci. 4(2): 274-288, 2010

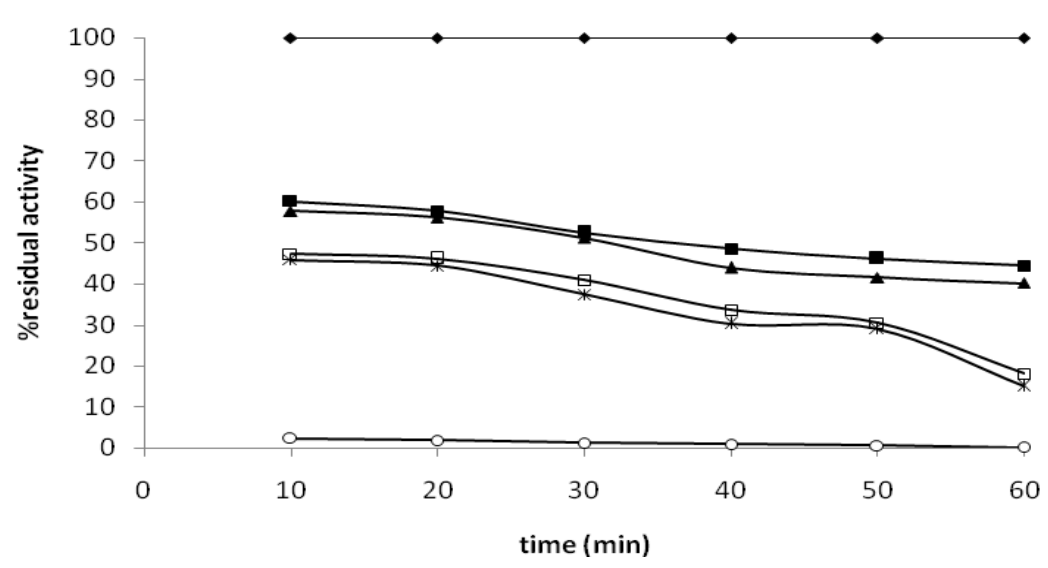

Figure 10: The heat stability profile of the enzyme. The heat stability of the enzyme was investigated between $30^{\circ} \mathrm{C}$ and $80^{\circ} \mathrm{C}$. Aliquots of $1.0 \mathrm{ml}$ of the purified enzyme was incubated at the indicated temperature. Assays were in a 25 $\mathrm{mM}$ borate buffer, $\mathrm{pH}$ 9.4. The assay mixture was first incubated at the indicated temperatures for $10 \mathrm{~min}$ before the reaction was initiated by the addition of the enzyme. $30^{\circ} \mathrm{C}(\bullet), 40{ }^{\circ} \mathrm{C}(\boldsymbol{\bullet}), 50{ }^{\circ} \mathrm{C}(\Delta), 60{ }^{\circ} \mathrm{C}\left(\right.$ (口) $70{ }^{\circ} \mathrm{C}$ (ж) and $80{ }^{\circ} \mathrm{C}(\circ)$

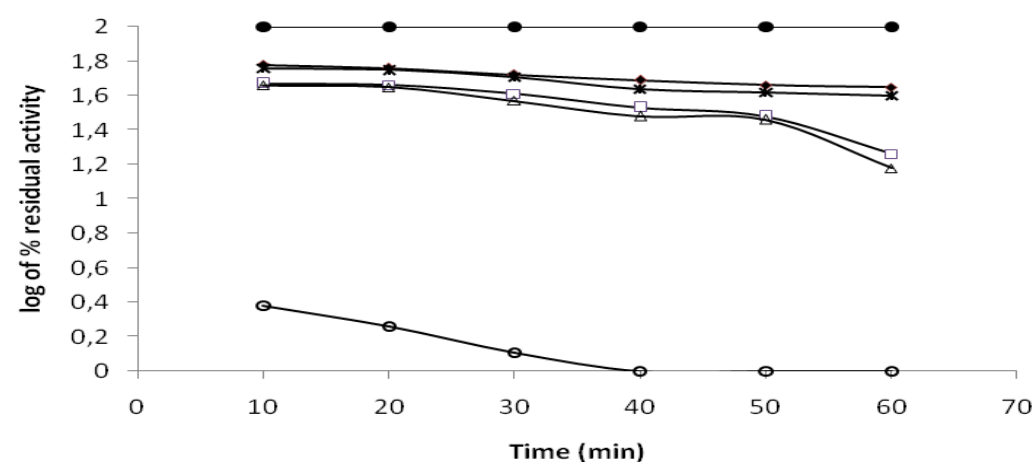

Figure 11: The plot of log of $\%$ residual activity against time for the determination of half-life of the enzyme. The assay condition is as described in the test.

$30^{\circ} \mathrm{C}(\bullet), 40^{\circ} \mathrm{C}(\bullet), 50^{\circ} \mathrm{C}\left(\right.$ ж), $60^{\circ} \mathrm{C}(\square), 70^{\circ} \mathrm{C}(\Delta)$ and $80^{\circ} \mathrm{C}($ ( )

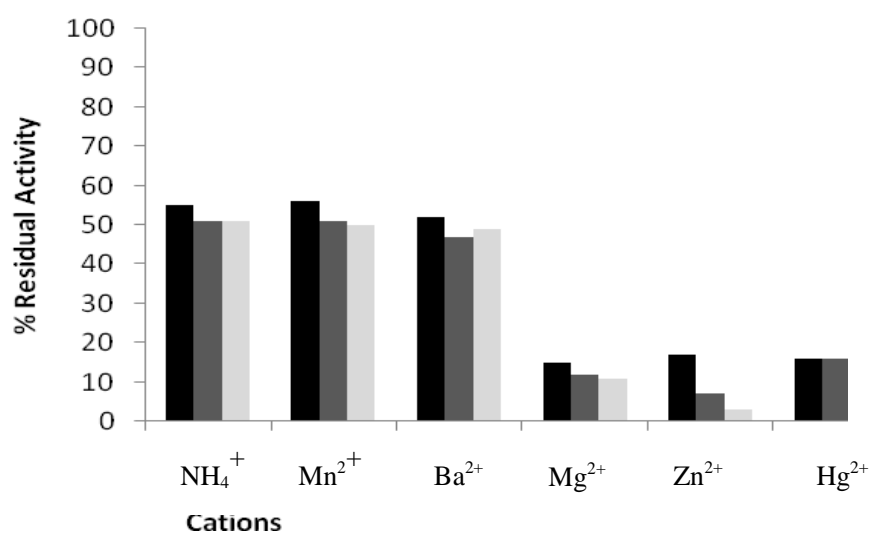

Figure 12: Effects of cations on enzyme activity. Enzyme assays were carried out under standard assay condition as described in the test. The final concentrations of each cation in the assay mixtures were $125 \mu \mathrm{M}$ ), $250 \mu \mathrm{M}$ and $500 \mu \mathrm{M}$. 
Table 5: Half-life of soldier termite rhodanese.

\begin{tabular}{cc}
\hline Temperature $\left({ }^{\mathbf{0}} \mathbf{C}\right)$ & Half-life $\left(\mathbf{T}_{\mathbf{1 / 2}}\right)[\mathbf{M i n}]$ \\
\hline 40 & 150.7 \\
50 & 60.3 \\
60 & 43.0 \\
70 & 38.0 \\
80 & 37.0
\end{tabular}

The experiment is as described in the text.

\section{DISCUSSION}

Rhodanese has been reported in many organisms from bacteria to animals (Sorbo, 1951; Jarabak and Westley, 1974; Anosike and Ugochukwu, 1981; Lee et al., 1995; Agboola and Okonji, 2004; Saidu, 2004; Akinsiklu et al., 2009; Aladesanmi et al., 2009). The enzyme has been found and reported to be widely distributed in both adults and larvae of insects and was not restricted to those species which encounter exogenous cyanide through feeding on cyanogenic plants (Beesly et al., 1986). Indeed, recent studies have clearly shown that rhodanese is involved in energy metabolism through its participation in regulation of mitochondrial electron transport and in the biosynthesis of iron-sulfur centers (Toohey, 1989; Aminlari et al., 1994). Termites are social insects that build large nests in soil or wood and can occasionally cause damage to wooden structures (Hadlington, 1987; Gerozisis and Hadlington, 2001). However they belong to a completely different insect group (Order Isoptera) to true ants (Order Hymenoptera) (Hadlington, 1987; Gerozisis and Hadlington, 2001). Many species feed on wood, grass and other matter which have been found to contain cyanogenic glycosides and on ingestion release cyanide (Woods and Calnan, 1976; Jagels, 1985; Conn, 2008). The soldier termites are the colony defenders (Hadlington, 1987; Gerozisis and Hadlington, 2001).

Rhodanese from soldier termite was purified by ammonium sulphate precipitation,
Reactive Blue-2 agarose affinity chromatography and gel filtration on Sephadex G-150. The enzyme had a specific activity of $7.9 \mathrm{RU}$ per $\mathrm{mg}$ of protein and a $10.4 \%$ recovery. Agboola and Okonji (2004) obtained $136.6 \mathrm{RU} / \mathrm{mg}$ for fruit bat liver rhodanese, Sorbo (1953a) and Himwich and Saunders, (1948) obtained $256 \mathrm{RU} / \mathrm{mg}$ and $131 \mathrm{RU} / \mathrm{mg}$ respectively for bovine liver rhodanese. Akinsiku et al. (2009) obtained a value of 73 and $72 \mathrm{RU} / \mathrm{mg}$ for catfish rhodanese I (cRHDI) and catfish rhodanese II (cRHDII) respectively.

Different investigators have reported various molecular weights values for rhodanese from a variety of different sources: bovine liver (37,000 dalton; Sorbo 1953a), human liver (37,000 dalton; Jarabak and Westley 1974), mouse liver (34,800 dalton; Lee et al., 1995) and rat liver (34,000 dalton; Nagahara and Nishino, 1996). The native molecular weight determined by Sephadex G150 was 37,154 dalton for soldier termite rhodanese and the subunit molecular weight obtained from SDS-PAGE was 32,210 dalton. The native molecular weight value is very similar to those obtained by Sorbo (1953a) and Jarabak and Westley (1974), which was 37,000 dalton for bovine liver and human liver rhodanese. This result suggests that the enzyme is a monomeric protein. While Jarabak and Westley (1974) showed that purified human liver rhodanese is a monomeric protein, other researchers have shown that they are dimers of two identical subunits of molecular weights 18,000-19,000 
dalton (Blumenthal and Heinrikson 1971; Volini et al., 1967). Volini et al. (1967) reported that bovine rhodanese existed as a monomer-dimeric molecule of molecular weight of 18,000-36,000 dalton. Russell et al., (1978) and Ploegman et al., (1978), based on a three-dimensional structure analysis, showed that bovine liver mitochondrial rhodanese is a single polypeptide chain with a molecular weight of 32,000 dalton. Akinsiku et al. (2009) recently reported two forms of rhodaneses cRHD I and cRHD II with very similar molecular weight of about 35,000 dalton. They proposed that it is possible the two forms are monomeric and aggregate forms of one of the other. According to Lee et al. (1995) the molecular weight of mouse liver rhodanese that is non-denatured by gel filteration on a sephacryl G-150 column was found to be 34,500 dalton and the same molecular weight determined by SDS-PAGE indicated 34,000 dalton, suggesting that the enzyme is a monomeric globular protein. However, that rhodanese stored at $-70^{\circ} \mathrm{C}$ for over 3 weeks showed that the protein split into 2 identical subunits, $\mathrm{M}_{\mathrm{r}}$. of 27,000 dalton (Lee et al., 1995)

The $\mathrm{K}_{\mathrm{m}}$ values of $7.0 \mathrm{mM}$ and $5.3 \mathrm{mM}$ were obtained for $\mathrm{KCN}$ and $\mathrm{Na}_{2} \mathrm{~S}_{2} \mathrm{O}_{3}$ respectively. These values compares very well to previous work reported on the enzyme (Table 3). These results, however are lower than those reported for fruit bat liver (Agboola and Okonji, 2004: $13.36 \mathrm{mM}$ and $19.15 \mathrm{mM}$ for $\mathrm{KCN}$ and $\mathrm{Na}_{2} \mathrm{~S}_{2} \mathrm{O}_{3}$ respectively), catfish liver (Akinsiku et al., 2009: $25.4 \mathrm{mM}$ and 18.6 $\mathrm{mM}$ for $\mathrm{KCN}$ and $\mathrm{Na}_{2} \mathrm{~S}_{2} \mathrm{O}_{3}$ respectively) indicating that the affinity of the soldier termite enzyme for these substrates is higher than that of the other enzymes and that it would catalyze the detoxification reaction more efficiently. This effective enzymatic system may be due to a higher exposure to cyanide ingested continually from their diet. It is also possible that the major function of rhodanese in soldier termite is cyanide detoxification, since rhodanese has been shown to be involved in other physiological roles (including the supply of sulphide for the formation of iron sulphur centres for electron transport chain).

Sorbo (1953b) studied the ability of different thiosulpohates, (e.g. benzenethiosulphonate, ethane thiosulphonates, and nbutane-thiosulphonates) to replace thiosulphate in rhodanese reaction. Cyanide and thiosulphate were reported to be acceptor substrates (Sorbo, 1953b; Westley, 1980), while sulphite, persulphide and sulphinates were reported to serve as donor substrates (Sorbo, 1957; Villarejo and Westley, 1963; Nagahara et al., 1999). In this work, the specificity study (Table 4) showed that soldier termite rhodanese was specific for thiosulphate as substrate acceptor for sulphane-sulphur transfer in rhodanese catalytic mechanism, while been inhibited by sulphide, sulphite and sulphate (Table 4). The inhibitory effects of sodium sulphide, dithiobiuret and cystein have been reported to be due to the blocking of the enzyme active site (Himwich and Saunders, 1948).

Different optimum temperatures have been reported for rhodaneses from different organisms. The optimum temperature of $55^{\circ} \mathrm{C}$ obtained for soldier termite rhodanese is in good agreement with the results reported for rhodaneses from different sources. Himwich and Saunders (1948) obtained an optimum temperature between $38{ }^{\circ} \mathrm{C}$ and $40{ }^{\circ} \mathrm{C}$ for bovine liver rhodanese. Sorbo (1953a) also working with bovine liver reported an optimum temperature of $50{ }^{\circ} \mathrm{C}$. Chew and Boey (1972) reported an optimum temperature of $59{ }^{\circ} \mathrm{C}$ for tapioca leaves. Ezzi et al. (2003) obtained a wide temperature optimum of 35$55{ }^{\circ} \mathrm{C}$ for rhodanese enzyme in all the Trichoderma strains. Agboola and Okonji (2004) showed the presence of rhodanese in the cytosolic fraction of fruit bat liver with an optimum temperature of $35^{\circ} \mathrm{C}$. Hadlington (1987) had shown in his work that termites' nests are usually maintained at a temperature between $25^{\circ} \mathrm{C}-36{ }^{\circ} \mathrm{C}$. With the level of metabolic activity that involves degradation of wood and/or other food materials that allow 
microbial activity to thrive in their habitat which may result in the release of heat. This ambient temperature may have conditioned the enzyme to function at higher temperatures.

The heat stability experiments showed that soldier termite rhodanese was stable up to $60{ }^{\circ} \mathrm{C}$ for about 30 minutes at $\mathrm{pH}$ 9.4. Agboola and Okonji (2004) and Akinsiku et al. (2009) reported similar results with fruit bat liver rhodanese and catfish liver rhodanese respectively. The half-life values of soldier termite rhodanese obtained from the plot of $\log$ of percentage residual activity against time is presented in Table 5.

Soldier termite rhodanese showed maximum activity at $\mathrm{pH}$ 8.0. The optimum $\mathrm{pH}$ ranges of 8.0-11.0 have been reported for different organisms (Sorbo, 1951; Jarabak and Westley, 1974; Anosike and Ugochukwu, 1981; Lee et al., 1995; Agboola and Okonji, 2004; Saidu, 2004; Okonji et al., 2008). Recently, Okonji et al. (2008) and Akinsiku et al. (2009) reported an optimum $\mathrm{pH}$ as low as 6.0 and 6.5 for giant fresh water prawn $(M$. rosenbergii) hepatopancreas and catfish liver respectively, both of aquatic origin. The low $\mathrm{pH}$ in these two aquatic lives was reported to be physiologically significant for the survival of the organisms in their environment. Research has shown that decaying wood does not increase acidification of the soil (Kayahara, 2001). Various metabolic activities in the environment of termite may be responsible for the slightly alkaline $\mathrm{pH}$ of soldier termite rhodanese.

The effect of cations on the activity of rhodanese showed that the soldier termite enzyme was inhibited considerably $(\leq 20 \%)$ by $\mathrm{Mg}^{2+}, \mathrm{Zn}^{2+}$ and $\mathrm{Hg}^{2+}$ (Figure 9). $\mathrm{NH}_{4}{ }^{+}, \mathrm{Mn}^{2+}$ and $\mathrm{Ba}^{2+}$ showed no significant inhibition on soldier termite rhodanese. Agboola and Okonji (2004) reported the inhibition of bat liver rhodanese by $\mathrm{Ba}^{2+}$, while $\mathrm{Zn}^{2+}$ was reported to inhibit African catfish (Clarias gariepinus) liver rhodanese (Akinsiku et al., 2009). $\mathrm{Zn}^{2+}$ and $\mathrm{Hg}^{2+}$ have been known to be potent inhibitors of rhodanese through their interactions with side chain residues of rhodanese active site (Vallee and Ulmer, 1972; Agboola and Okonji, 2004).

In conclusion, the study demonstrates the physicochemical properties of the enzyme in soldier termite which compares very well with the reports of the enzyme from other sources. However, the results of this study may indicate the involvement of rhodanese in cyanide detoxification in soldier termite or an indication of a different sulfur transferase activity and sulphane-sulfur metabolism in the organism.

\section{REFERENCES}

Agboola FK, Okonji RE. 2004. Presence of Rhodanese in the Cytosolic Fraction of the Fruit Bat (Eidolon helvum) Liver. J. Biochem. Mol. Biol., 37(3): 275-281.

Akinsiku OT, Agboola FK, Kuku A, Afolayan A. 2009. Physicochemical and kinetic characteristics of rhodanese from the liver of African catfish Clarias gariepinus Burchell in Asejire Lake. Fish Physiol Biochem., DOI 10.1007/s10695-0099328-4.

Aminlari M, Gilanpour H, Taghavianpour H, Vaseghi T. 1989. Comparative studies onthe distribution of rhodanese and betamercaptopyruvate sulphurtransferase in differrent organs of sheep (Ovis aries) and cattle (Bos taurus). Comp. Biochem. Physiol., 92: 259-262.

Aminlari M, Gholami S, Vaseghi T, Azarafrooz A. 1997. Rhodanese (thiosulphate:cyanide sulphurtransferase) in the digestive tract of chicken at different stages of development. Poult. Sci., 76: 318-320.

Aminlari M, Li A, Kunanithy V, Scaman CH. 2002. Rhodanese distribution in porcine (Sus scrofa) tissues. Comp. Biochem. Physiol., 132B: 309-313.

Aminlari M, Malekhusseini A, Akrami F, Ebrahimnejad H. 2007. Cyanide metabolizing enzyme rhodanese in human tissues: comparison with domestic animals. Comp. Clin. Path., 16(1): 47-51. 
Anosike EO, Ugochukwu EN. 1981. Characterization of rhodanese from cassava leaves and tubers. J. Exp. Bot. 32: 1021-1027.

Atkinson A. 1975. Bacterial Cyanide Detoxification. Biotechnol. Bioenerg., 17(3): 457-460.

Beesley SG, Compton SG, Jones DA. 1985. Rhodanese in Insects. J. Chem. Ecol. 11(1): 45-50.

Blumenthal KM, Heinrikson RL. 1971. Structural Studies of Bovine Liver Rhodanese: I. Isolation and Characterization of two Active Forms of the Enzymes. J. Biol. Chem., 246(8): 2430-2437.

Borowitz JL, Kanthasamy AG, Isom GE. 1992. Toxicodynamics of cyanide. In Chemical Warfare Agents, Somani SM (ed). Academic Press: San Diego; 209-236.

Bradford KM. 1976. A rapid and sensitive method for the quantitation of micrograme quantities of protein utilizing the principle of protein-dye binding. Anal. Biochem., 72: 248-254.

Buzaleh AM, Vazquez ES, Battle AMD. 1990. the effect of cyanide intoxication on hepatic rhodanese kinetics. Gen. Pharmacol., 21(2): 219-222.

Chew MY, Boey CG. 1972. Rhodanese of tapiocal leaf. Phytochem., 11: 167-160.

Conn EE. 2008. Our work with cyanogenic plants. Ann. Rev. Plant Biol., 59: 1-19

Ezzi MI, Pascual JA, Gould BJ, Lynch JM. 2003. Characterisation of the rhodanese enzyme in Trichoderma spp. Enzy. Microb. Tech., 32(5): 629-634.

Gerozisis R, Hadlington P. 2001. Urban Pest Management $\left(4^{\text {th }}\right.$ edn). University of New South Wales Press.

Hadlington P. 1987. Australian Termites and Other Common Timber Pests. UNSW Press.

Himwich WA, Saunders JB. 1948. Enzymic conversion of cyanide to thiocyanate. Amer.Physiol., 53: 348-354.
Horowitz PM, DeToma F. 1970. Improved preparation of Bovine Liver Rhodanese. J. Biol. Chem. 245(6): 984-985.

Horowitz P, Westley J. 1970. Some Molecular Properties of rhodanese. J. Biol. Chem., 245(5): 984-985.

Jarabak R, Westley J. 1974. Human Liver Rhodanese: Nonlinear Kinetic Behaviour. Double Displacement Mechanism. Biochem., 13(16): 3233-3236.

Kayahara G. 2001. Comparison of soil acidification and intensity of podzolization beneath decaying wood versus non-woody Forest Floors in Coastal BC. (Karel Klinka ed.) Forest Sciences Department. The University of British Columbia, pp. 1-4

Lee CH, Hwang JH, Lee YS, Cho KS. 1995. Purification and Characterization of mouse liver rhodanese. J. Biochem. Mol. Biol., 28: 170-176.

Lineweaver H, Burk D. 1934. The determination of enzyme dissociation constants. J. Amer. Chem. Soc., 56: 658666.

Nahagara N, Nishino T. 1996. Role of Amino acid residues in the active site of rat liver mercaptopyrivate sulphurtransferases. $J$. Biol. Chem., 271(44): 27395-27401.

Nagahara N, Ito T, Minam M. 1999. Mecaptopyruvate sulphurtransferase as a defence against cyanide toxications; Molecular properties and mode of detoxification. Histol. Histopath., 14: 1277-1286.

Okonji RE, Aladesanmi OT, Kuku A, Agboola FK. 2008. Isolation and some properties of partially purified rhodanese from the hepatopancreas of giant freshwater prawn (Macrobrachium rosenbergii De Man). Ife J. Sci., 10(2): 255-262

Saidu Y. 2004. Physicochemical features of rhodanese: A review. Afri. J. Biotech., 3(4): 370-374.

Sorbo BH. 1951. On the properties of Rhodanese. Acta Chem. Scand., 5: 724726. 
Sorbo BH. 1953a. Crystalline Rhodanese. Acta Chem. Scand. 7: 1129-1136.

Sorbo BH. 1953b. Crystalline Rhodanese. enzyme catalyzed reaction. Acta Chem. Scand., 7: 1137-1145.

Tabatabai MA, Singh BB. 1976. Rhodanese Activity of Soil. Soil Sci. Soc. Amer. J., 40: 381-385.

Ulmer DD, Vallee BL. 1972. Role of metals in sulphurtranferases activity. Ann. Rev. Biochem., 32: 86-90.

Volini M, DeToma F, Westley J. 1967. Dimeric structure and zinc content of bovine liver Rhodanese. J. Biol. Chem., 242(22): 5229-5225.

Wang SF, Volini M. 1968. Studies on the active site of Rhodanese. J. Biol. Chem., 243(20): 5465-5470.
Weber K, Osborn M. 1975. Protein and sodium dodecyl sulphate. Molecular weight determination, polyacrylamide gel and related procedures. In The Proteins ( $3^{\text {rd }}$ edn), Newrath H, Hill RL (eds). Academic Press: New York. 1; 179-223.

Westley J. 1973. Rhodanese. Adv. Enzymol. Relat. Areas Mol. Biol., 39: 327-368.

Westley J. 1980. Rhodanese and the Sulphane Pool. Enzymatic Basis of Detoxification (Vol. II). Academic Press Inc.; 245-259.

Westley J. 1981. Cyanide and sulfane sulphur. In Cyanide in Biology, Vennesland B, Conn EE, Knowles CJ, Westley J, Wissing F (eds). Academic Press: NewYork; 61-76. 